DOI: http://dx.doi.org/10.17651/ONOMAST.63.26

Onomastica LXIII, 2019

PL ISSN 0078-4648

\title{
UTWORZENIE POLSKIEGO TOWARZYSTWA ONOMASTYCZNEGO
}

6 października 2018 r. polscy onomaści zgromadzeni na 21. MiOKO w Kazimierzu Dolnym podjęli decyzję o powołaniu Polskiego Towarzystwa Onomastycznego jako stowarzyszenia rejestrowego. W dniu 5 listopada 2018 r. PTO zostało wpisane do Krajowego Rejestru Sądowego pod numerem KRS 0000755603, uzyskując tym samym osobowość prawną i stając się pierwszym towarzystwem onomastycznym w krajach słowiańskich. W marcu 2019 r. PTO uzyskało afiliację w International Council of Onomastic Sciences, dołączając do innych zrzeszonych tam narodowych towarzystw onomastycznych (m.in. American Name Society, Deutsche Gesellschaft für Namenforschung, Société française d'onomastique).

Z inicjatywą powołania ogólnopolskiej organizacji onomastycznej wystąpili przedstawiciele młodego pokolenia onomastów. Najważniejszym celem było utworzenie niezależnego podmiotu posiadającego osobowość prawną, który mógłby zapewniać formalne i instytucjonalne wsparcie wielu tradycyjnym i nowym przedsięwzięciom polskich onomastów. Komplementarność wobec wszelkich dotychczasowych form organizacji polskiego naukowego życia onomastycznego jest od początku wpisana w ideę utworzenia PTO.

Istotnym celem, jakie stawia sobie nowo powołane stowarzyszenie, jest zwiększanie widoczności badań onomastycznych w polskiej i międzynarodowej społeczności naukowej, w szczególności wśród językoznawców niebędących onomastami. Służyć będą temu działania networkingowe oraz inicjowanie i wspieranie międzynarodowej współpracy onomastycznej.

Wszyscy członkowie PTO poruszają w swoich badaniach tematykę nazw własnych, choć nie dla wszystkich onomastyka jest ich prymarną subdyscypliną językoznawczą. Taki inkluzywny i inter(sub)dyscyplinarny charakter organizacji jest dla nas bardzo ważny.

Wszystkich zainteresowanych zapraszamy do współpracy. Więcej informacji o Towarzystwie dostępnych jest pod adresem pto.org.pl. 